\title{
REFLECTION
}

\section{Cultivating the Inner Life of a Physician Through Written Reflection}

\author{
Andrea Vicini, SJ, MD, PbD \\ Allen F. Shaughnessy, PharmD, \\ MMed $E d^{2}$
}

Asbley P. Duggan, $P b D^{3}$

'School of Theology and Ministry, Boston College, Boston, Massachusetts

${ }^{2}$ Department of Family Medicine, Tufts University School of Medicine, Malden Massachusetts

${ }^{3}$ Communication Department, Boston College, Boston, Massachusetts
Conflicts of interest: authors report none.

\section{CORRESPONDING AUTHOR}

Allen F. Shaughnessy, PharmD, MMed Ed Department of Family Medicine Tufts University School of Medicine 195 Canal Street,

Malden, MA 02148

ashaughnessy@challiance.org

\begin{abstract}
All of us have an "inner life" that forms the core of who we are. It shapes and is shaped by our actions and experiences. During physician training, attention to residents' inner life requires a focus on their beliefs and emotions as well as their ethical and spiritual development, topics often considered to be outside the realm of clinical training and practice. We suggest that written reflections, as part of medical residency curriculum, can allow residents to explore their inner lives. The depth and range of residents' explorations show the value of adding brief, protected time for residents to explore their hopes, joys, struggles, and feelings, and to develop meaning from their experiences with patients.
\end{abstract}

Ann Fam Med 2017;15:379-381. https://doi.org/10.1370/afm.2091.

\section{CULTIVATING REFLECTION IN RESIDENCY TRAINING}

In medical education, written reflective exercises are used to assess learners' critical thinking skills, clinical reasoning, and metacognition about professionalism. ${ }^{6}$ We introduced reflective writing into a family medicine residency to nurture self-development without using it as an assessment method. Three times a week in 15 -minute slots in their family medicine clinic schedules, residents wrote written reflections about their experiences with patients. We did not provide specific writing prompts. Residents wrote for their own growth, not for a grade. Following residents' graduation we removed identifying information and analyzed written reflections for thematic content. ${ }^{7,8}$

We discovered some of these writings reflected the struggles residents' experience, not only in their clinical practices, but also in their personal development. In these reflections residents indicated attentiveness to expressions of their longings and desires, their self-doubt and feelings of helplessness. These writings (paraphrased to disguise identifying details) 
often described their struggles and frequently ended not in futility but with a goal for the future:

"Somewhere in intern year I lost my softness and didn't realize it until yesterday. A simple class on mindfulness reminding me of my roots in mind-body medicine, my inner peace, and the tremendous value of a mindful path for personal healing, composure and compassion as a physician, and for teaching my patients for managing their own illnesses, struggles, pain, anxieties, etc."

"I like doing things that give me a sense of purpose and meaning in my life so that is a selfish goal but a real one. I hope to volunteer my time to do something that will remind me of the underlying reason I went into medicine. And I hope to have fun."

"In all these days of doubting myself and what I know, at least I feel like I'm connecting with people on a personal level, gaining their trust, etc., which is at least half the battle."

"Today, today I felt... helpless... overwhelmed... scared. Tomorrow will be different, but today will not be forgotten."

At other times, residents recognize their joy, gratitude, and hope connected to clinical experiences:

"I'm happy to see everyone when I get to work, so that's a definite positive."

"My simple act of being compassionate enough to recognize the need of the family, and then taking the time to meet them, meant everything to the family and for this she wanted to thank me."

"Ultimately I feel hopeful that this is an amazing time to be going into the medical field."

Residents also used the written reflections to explore their own personal growth (or the need for it) and to try to create meaning from their experiences:

"It is important for me to remember medical school as I embark on this new journey as a resident physician. Not only will it allow me to see my personal growth, continued learning needs, and give me some sense of accomplishment, but it will also make me a more understanding, compassionate team member and teacher."

"I stand here before you-with my hands open-in prayer and gratitude for your guidance and love. I pray to be of service today. To be a woman for dignity, honor and grace. I pray to slow down, to take the signs of the universe. To be kind to myself and to others, to breath, to believe, to realize I am not the one in charge here.

"I'm feeling super frustrated today because I have to fill in for [resident] who called out sick for night clinic with 'conjunctivitis and a sore throat.' I was really looking forward to a night off and heading to the movies with one of my buddies. I've been thinking about it all day trying to figure out why it has me so pissed off."

"Most importantly at this point is the reminder that there are endless opportunities and connections in this universe waiting to exist and grow. This idea that I keep discovering over and over again is the most powerful and life affirming discovery and I hope to God that this continues to feel new and exciting."

When left to express their own inner life for their own purposes, residents used the opportunity to explore existential questions alongside their explorations of their clinical knowledge and skills. In focus groups conducted following the institution of the reflective exercises, all participants expressed a desire to reflect on their future and a realization of the value in reflection. ${ }^{9}$ Written reflection was seen as a creative activity or a potential source of creativity. One resident described the benefit of, "being able to put my jumbled thoughts out there and make some sense out of them." Another described the reflections as a ". . process of stepping back and looking at the sort of meta picture of it, the idea of being intentional about how I think and how I go about things."

Prompted by these writing exercises, residents expressed desire for sharing and discussion about their growth, to normalize their thoughts and feelings with their peer group: ". . how I get my head around emotional things that have happened in my day is by talking to people." Another commented, "For me just to write it doesn't do as much for me as also sharing it, sharing the story and getting feedback."

Since the reflections were collected in the residents' computer portfolio, we offered the option for them to share their reflections with either their classmates or the wider residency community, which some chose to do. We also set aside time periodically for discussion following the writing.

These reflections illustrate explorations of the inner life-a part of growing as both a person and a physician. Written reflection allows the expression of emotions that physicians may be unable or discouraged from exploring in typical training programs or with colleagues. As exemplified by the (public) reflections of Atul Gawande, MD, developing physicians can struggle with uncertainty ${ }_{1}^{10}$ mistakes, and failure, and look for right solutions. ${ }^{11}$ In a protected space, physicians can express the multiple dimensions of their humanity noticed in movements of the inner life. They can question troubling human experiences. They can face the ethical issues that surface. They can address spiritual and religious beliefs and practices, of their own and their patients. ${ }^{12}$ 


\section{NURTURING ONE'S INNER LIFE}

Written reflections can nurture multi-dimensionality in physicians' inner lives. The joy of medical practice arises from a job-well-done technical prowess coupled with the service toward those who are suffering and in need of care. ${ }^{13}$ However, the Triple Aim of improving the health of populations, enhancing the patient experience of care, and reducing the cost of health care, without commensurate focus on the work life of physicians, can wring the joy out of practice. ${ }^{14}$

As medical practice moves headlong toward a technical rationality ${ }^{15}$ that seems reasonable on a spreadsheet but misses the softer tone of what we hope happens in the exam room, let us be sure to support and nurture the inner life of the physicians generating these numbers while trying to provide more holistic clinical care. It contrasts with emphasis on a "detached concern ${ }^{\prime \prime 16}$ that somehow is supposed to protect one's objectivity but which also prevents complete engagement with another individual. A more realized human is a better doctor. Written reflection can foster the more realized person as physician.

To read or post commentaries in response to this article, see it online at http:I/www.AnnFamMed.org/content/15/4/379.

Submitted September 14, 2016; submitted, revised, February 13, 2017; accepted March 19, 2017.

Key words: quality of health care; quality of life; spirituality; professional/prevention \& control/psychology; professional role

Acknowledgments: The authors are grateful for the thoughtful contributions of Lucas Allen and Katherine Donahue, who were research assistants on this project.
2. Kotva JJ. The Christian Case for Virtue Ethics. Washington, D.C.: Georgetown University Press; 1996.

3. Maclntyre AC. After Virtue : A Study in Moral Theory. 2nd ed. Notre Dame, IN: University of Notre Dame Press; 1984.

4. Keenan JF. Virtue ethics and sexual ethics. Louv Stud. 2005;30: 180-197.

5. Fredrickson BL, Losada MF. Positive affect and the complex dynamics of human flourishing. Am Psychol. 2005;60(7):678-686.

6. Wald HS, Davis SW, Reis SP, Monroe AD, Borkan JM. Reflecting on reflections: enhancement of medical education curriculum with structured field notes and guided feedback. Acad Med. 2009;84(7):830-837.

7. Vicini A, Shaughnessy AF, Duggan A. On the inner life of physicians: analysis of family medicine residents' written reflections [published online ahead of print April 19, 2017]. J Relig Health. doi: 10.1007/s10943-017-0394-0.

8. Shaughnessy AF, Allen L, Duggan A. Attention without intention: explicit processing and implicit goal-setting in family medicine residents' written reflections. Educ Prim Care. 2017;28(3):150-156.

9. Shaughnessy AF, Duggan AP. Family medicine residents' reactions to introducing a reflective exercise into training. Educ Health (Abingdon). 2013;26(3):141-146.

10. Gawande A. Complications: A Surgeon's Notes on an Imperfect Science. 1st ed. New York, NY: Metropolitan Books; 2002.

11. Gawande A. Better:A Surgeon's Notes on Performance. 1st ed. New York, NY: Metropolitan Books; 2007.

12. Singh DK, Ajinkya S. Spirituality and religion in modern medicine. Indian J Psychol Med. 2012;34(4):399-402.

13. Egnew TR. Suffering, meaning, and healing: challenges of contemporary medicine. Ann Fam Med. 2009;7(2):170-175

14. Bodenheimer T, Sinsky C. From triple to quadruple aim: care of the patient requires care of the provider. Ann Fam Med. 2014;12(6): 573-576.

15. Schön DA. The Reflective Practitioner. How Professionals Think in Action. Basic Books; 1983.

16. Fox J. "Notice how you feel": an alternative to detached concern among hospice volunteers. Qual Health Res. 2006;16(7):944-961.

\section{References}

1. Good MJ. The inner life of medicine: a commentary on anthropologies of clinical training in the twenty-first century. Cult Med Psychiatry. 2011;35(2):321-327. 